\title{
KEDUDUKAN DAN TANGGUNG JAWAB NOTARIS PENERIMA PROTOKOL NOTARIS YANG MENINGGAL DUNIA
}

\author{
Eko Permana Putra \\ Univertsitas_Andalas, eko_24@ymail.com
}

\begin{tabular}{|l|l|l|}
\hline Diterima: 16 Januari 2020 & Direvisi : 07 Juli 2020 & Diterbitkean: 09 Juli 2020 \\
\hline
\end{tabular}

\begin{abstract}
According to 87th Article of the Criminal Code, if treason has commenced according to Article 53th of the Criminal Code (Trial), on the other hand, there is a The1945 Constitution which is a Grundnorm that guarantees the freedom to express opinions that publicly as in 28th E Article, 3rd paragraph. And also, regulated explicitly in 39th Law Number, the year 1999 about expressing opinions in public, so if referring to treason as an experiment as Article 53 of the Criminal Code, it would prevent anyone from criticizing by communicating and issuing opinions. If the notice was addressed to the government by saying the current government is not good and must be replaced, the presence of the 87th Article about the Criminal Code certainly experiments intention. And the crimes against state security are also referred to as political offenses, to determine the suspects in this political offense, an in-depth study must be carried out, so this is the reason why the writing is carried out. The typology of the research used is the normative juridical (doctrinal) library method. So in this study, we can see whether it is appropriate if the criminal offense of this treason can be applied as the 87th Article about Criminal Code without interpreting the betrayal as an aanslag or attempt or an attack connected to the existence of Guarantees in Delivering Opinions.
\end{abstract}

Keywords: The Freedom in Delivering Opinions, Treason, Aanslag.

\begin{abstract}
Abstrak
Menurut pasal 87 KUHP adalah apabila telah dimulainya perbuatan makar sebagaimana menurut pasal 53 KUHP (Percobaan), disisi lain terdapat UUD 1945 yang merupakan Grundnorm yang menjamin kebebasan menyampaiakan pendapat dimuka umum termaktub dalam Pasal 28E ayat 3, dan juga diatur secara spesifik dalam UU Nomor 39 Tabun 1999 tentang menyampaikan pendapat dimuka umum, sehingga jika merujuk makar sebagai suatu percobaan sebagaimana Pasal 53 KUHP, akan menghambat setiap orang untuk. mengkritisi dengan menyatakan dan mengeluarkan pendapat, jikapendapat tersebut ditujukan kepada pemerintah dengan mengatakan pemerintah saat ini tidak baik dan harus diganti, dengan kehadiran Pasal 87 KUHP tentu menjadikan percobaan dalam niat. Dan kejahatan terbadap keamanan negara juga disebut sebagai delik politik, tentu untuk menetapkan tersangka dalam delik. politik ini barus dilakukan kajian mendalam, maka untuk itu penulisan ini dilakukan pendekatan Tipologi penelitian yang digunakan adalah metode kepustakaan yang bersifat yuridis normatif (doktriner). Sebingga kajian ini dapat melihat apakah tepat jika tindak pidana makar ini dapat diterapkan sebagaimana Pasal 87 KUHP tampa mengartikan makar tersebut sebagai aanslag atau Atempt tau serangan dibubungkan dengan adanya Jaminan dalam Kebebasan Menyampaikan Pendapat.
\end{abstract}

Kata Kunci: Kemerdekaan Menyampaikan Pendapat, Makar, Aanslag.

\section{PENDAHULUAN}

Di dalam Undang-Undang Nomor 2 Tahun 2014 Perubahan Atas Undang-Undang Nomor 30 tahun 2004 tentang Jabatan Notaris, pengertian notaris disebutkan dalam Pasal 1 ayat (1): "Notaris adalah Pejabat Umum yang berwenang membuat akta otentik dan kewenangan lainnya sebagaimana dimaksud dalam Undang-Undang Nomor 2 Tahun 2014 Perubahan Atas Undang-Undang Nomor 30 Tahun 2004 tentang Jabatan Notaris".

Pada tahun 2004 dibentuklah UndangUndang Nomor 30 Tahun 2004 tentang Jabatan Notaris (sebagai pengganti Staatbald 1860 
Nomor 30) yang kemudian dirubah dengan Undang-Undang Nomor 2 Tahun 2014 tentang Jabatan Notaris. Selanjutnya dalam tulisan ini disingkat dengan Undang-Undang Jabatan Notaris (UUJN).

Pengertian notaris didalam UUJN secara tegas dinyatakan bahwa kewenangan notaris untuk membuat akta otentik. Dalam melaksanakan tugas jabatan sebagai notaris, secara langsung melekatlah sebuah tanggung jawab yang berkenaan dengan alat bukti yang dapat menentukan dengan jelas hak dan kewajiban seseorang sebagai subjek hukum. Melalui kewenangan tersebut notaris dapat memberikan pelayanan hukum dengan harapan kepastian hukum bagi masyarakat.

Notaris merupakan salah satu profesi yang ikut berperan aktif dalam mendukung proses penegakan hukum di dalam Negara Kesatuan Republik Indonesia melalui akta otentik yang dibuatnya. Kedudukan akta otentik tersebut tergambar dalam pasal 1868 Kitab Undang-Undang Hukum Perdata yang berbunyi sebagai berikut :"suatu akta otentik adalah suatu akta yang dalam bentuknya ditentukan Undang-Undang, yang dibuat oleh atau dihadapan pegawai-pegawai umum yang berkuasa untuk ditempat dimana akta dibuatnya"

Notaris sebagai pejabat publik yang mempunyai wewenang untuk membuat akta otentik dapat menjawab kebutuhan dan kepentingan masyarakat akan kepastian hukum, sebagaimana yang tertuang didalam perjanjian, perikatan dan kesepakatan yang dibuat oleh para pihak dalam bentuk akta otentik. Pembuatan akta otentik sebagai alat bukti yang sempurna dan tidak diperlukan lagi alat bukti lain untuk memperkuat dalil-dalil dalam suatu kasus hukum.

1. Habib Adjie, Sanksi Perdata dan Administratif Terhadap Notaris Sebagai Pejabat Publik, (Bandung: Refika Aditama, 2009), 45.
Akta otentik terdiri dari minuta akta dan salinan akta. Minuta akta disimpan oleh Notaris yang merupakan bagian dari protokol Notaris yang harus disimpan dan dipelihara oleh notaris karena merupakan arsip negara. Pasal 1 angka 8 UUJN disebutkan bahwa "Akta otentik yang disimpan sebagai protokol notaris adalah minuta akta yaitu asli akta yang mencantumkan tanda tangan para penghadap, saksi, dan Notaris yang disimpan sebagai bagian dari protokol notaris.

Selanjutnya pada Pasal 1 angka 13 UUJN disebutkan bahwa "Protokol notaris adalah kumpulan dokumen yang merupakan arsip negara yang harus disimpan dan dipelihara oleh notaris sesuai dengan ketentuan peraturan perundang-undangan".

Menurut Habib Adjie dalam salah satu bukunya menyebutkan bahwa "penyimpanan protokol notaris oleh notaris pemegang protokol merupakan suatu upaya untuk menjaga umur yuridis akta notaris sebagai alat bukti yang sempurna bagi para pihak atau ahli warisnya tentang segala hal yang termuat dalam akta tersebut. Akta notaris dalam bentuk salinan selamanya akan ada jika disimpan oleh yang bersangkutan, dan dalam bentuk minuta juga akan ada selamanya, yaitu yang disimpan oleh notaris sendiri atau oleh notaris pemegang protokol atau Majelis Pengawas Daerah. Meskipun notaris meninggal dunia tetapi akta notaris akan tetap ada dan mempunyai umur yuridis, melebihi umur biologis Notaris."

Mengenai penyerahan protokol notaris diatur dalam Pasal 63 Undang-undang No. 2 Tahun 2014 tentang Jabatan Notaris yaitu :

1. Penyerahan protokol sebagaimana dimaksud dalam pasal 62 dilakukan paling lama 30 (tiga puluh) hari dengan pembuatan berita acara penyerahan Protokol Notaris yang ditandatangani oleh 
yang menyerahkan dan yang menerima Protokol Notaris.

2. Dalam hal terjadi sebagaimana dimaksud dalam Pasal 62 huruf a, penyerahan Protokol Notaris dilakukan oleh ahli waris Notaris kepada Notaris lain yang ditunjuk oleh Majelis Pengawas Daerah.

3. Dalam hal terjadi sebagaimana dimaksud dalam Pasal 62 huruf g, penyerahan Protokol Notaris dilakukan oleh Notaris kepada Notaris lain yang ditunjuk oleh Majelis Pengawas Daerah jika pemberhentian sementara lebih dari 3 (tiga) bulan.

4. Dalam hal terjadi sebagaimana dimaksud dalam pasal 62 huruf b, huruf c, huruf d, huruff, atau huruf h, penyerahan Protokol Notaris dilakukan oleh Notaris kepada Notaris lain yang ditunjuk oleh Menteri atas usul Majelis Pengawas Daerah.

5. Protokol Notaris dari Notaris lain yang pada waktu penyerahan berumur 25 (dua puluh lima) tahun atau lebih diserahkan oleh Notaris penerima Protokol Notaris kepada Majelis Pengawas Daerah.

6. Dalam hal Protokol Notaris tidak diserahkan dalam jangka wabtu 30 (tiga puluh) hari sebagaimana yang dimaksud pada ayat (1), Majelis Pengawas Daerah berwenang untuk mengambil Protokol Notaris.

Notaris penerima protokol bukanlah pembuat akta dari protokol Notaris yang diserahkan kepadanya. Notaris penerima protokol dapat memberikan pelayanan terhadap klien/masyarakat dengan mengeluarkan grosse akta, salinan akta, dan kutipan akta dari minuta akta yang menjadi bagian dari protokol Notaris yang telah diserahkan kepadanya. Pasal 65 UUJNP menyatakan bahwa: Notaris, Notaris Pengganti, dan Pejabat Sementara Notaris bertanggung jawab atas setiap Akta yang dibuatnya meskipun Protokol Notaris telah diserahkan atau dipindahkan kepada pihak penyimpan Protokol Notaris.

Notaris penerima protokol notaris lain berkewajiban menyimpan akta ini tidak bertanggung jawab terhadap isi akta dari protokol Notaris yang diterimanya. Notaris berkewajiban secara langsung terhadap protokol Notaris. Kenyataannya di masyarakat saat ini tidak semua Notaris bisa memahami prosedur penyerahan protokol Notaris dan mau melaksanakan kewajibannya menyerahkan protokol Notaris kepada Notaris yang telah ditunjuk oleh Majelis Pengawas Daerah (selanjutnya disebut MPD) untuk menerima peralihan protokol Notaris. Notaris yang ditunjuk sebagai penerima protokol Notaris harus menyimpan dan memelihara protokol Notaris dengan baik selayaknya arsip Negara. Apabila kemudian hari terdapat sengketa maupun yang berhubungan dengan protokol Notaris yang telah diserahkan kepada Notaris penerima protokol Notaris, maka Notaris penerima protokol harus berhadapan dengan aparat penegak hukum.

Meninggalnya seorang Notaris, selain meninggalkan masalah-masalah mengenai pekerjaan yang tertunda tentunya juga akan meninggalkan permasalahan lainnya terkait dengan protokol Notaris. Notaris penerima protokol Notaris bukanlah pembuat akta dari protokol Notaris yang diserahkan kepadanya. Notaris penerima protokol dapat memberikan pelayanan terhadap klien atau masyarakat dengan mengeluarkan grosse akta, salinan akta dan kutipan akta dari minuta akta yang menjadi bagian dari protokol Notaris yang telah diserahkan kepadanya.

Oleh karena itu notaris penerima protokol sangat perlu mendapatkan perlindungan hukum sesuai kewenangan yang diperoleh Notaris. Berdasarkan uraian latar belakang, penelitian berfokus kepada kajian status hukum tentang Kedudukan dan Tanggung Jawab Notaris Penerima Protokol 
Notaris yang Meninggal Dunia. Fokusnya adalah untuk mengkaji bagaimana kedudukan hukum notaris penerima protokol atas notaris yang meninggal dunia dan bagaimana tanggung jawab notaris penerima protokol atas notaris yang meninggal dunia.

\section{METODE PENELITIAN}

Penelitian ini menggunakan penelitian hukum normatif yaitu yang penelitian terhadap asas-asas hukum, sistematika hukum, terhadap taraf sinkronisasi hukum, penelitian sejarah hukum dan penelitian perbandingan hukum. ${ }^{2}$ Jenis penelitian normatif atau metode library reseach (penelitian kepustakaan). Penelitian hukum yang dilakukan dengan cara meneliti bahan pustaka atau data sekunder. ${ }^{3}$

Sumber data dalam penelitian berasal dari penelitian kepustakaan (library research) dan penelitian lapangan (field research). Data/bahan hukum sekunder, yaitu bahan hukum yang dapat memberikan penjelasan terhadap bahan hukum primer, yang dapat berupa rancangan perundang-undangan, hasil penelitian, bukubuku teks jurnal ilmiah, surat kabar (Koran), pamphlet, lefleat, brosur, dan berita internet.

Jenis data yang dikumpulkan meliputi data sekunder dan data primer, dengan lebih mendalam ditujukan pada data sekunder. Untuk kebutuhan data sekunder diperoleh dari:
a. Peraturan Perundang-Undangan
b. Buku-buku, artikel dan jurnal hukum
c. Situs internet/website.

Bahan hukum dikumpulkan melalui prosedur inventarisasi dan identifikasi peraturan perundang-undangan, serta klasifikasi dan sistematisasi bahan hukum sesuai permasalahan penelitian. Oleh karena itu, teknik pengumpulan data yang digunakan dalam penelitian ini adalah dengan studi

2. Mukti Fajar dan Yulianto Achmad, Dualisme Penelitian Hukum Normatif dan Empiris, (Yogyakarta: Pustaka Pelajar, 2010), 153

3. Bambang Waluyo, Penelitian Hukum dalam Praktek, (Jakarta: Sinar Grafika, 2002), 13-14. kepustakaan. Studi kepustakaan dilakukan dengan cara membaca, menelaah, mencatat membuatulasan bahan-bahan pustaka yang ada kaitannya dengan protokol notaris atas notaris yang meninggal dunia.

Pada penelitian hukum normatif, pengolahan data dilakukan dengan mensistematika terhadap bahan-bahan hukum tertulis. Sistematisasi berarati membuat klasifikasi terhadap bahan-bahan hukum tersebut untuk memudahkan pekerjaan analisis dan konstruksi. ${ }^{4}$

Kegiatan yang dilakukan dalam analisis data penelitian hukum normatif dengan cara data yang diperoleh di analisis secara deskriptif kualitatif yaitu analisa terhadap data yang tidak bisa dihitung. Bahan hukumyang diperoleh selanjutnya dilakukan pembahasan, pemeriksaan dan pengelompokan ke dalam bagian-bagian tertentu untuk diolah menjadi data informasi.

\section{KEDUDUKAN NOTARIS PENERIMA PROTOKOL NOTARIS YANG MENINGGAL DUNIA}

Jabatan notaris diadakan atau kehadirannya dikehendaki oleh aturan hukum dengan maksud untuk melayani masyarakat yang membutuhkan alat bukti tertulis yang bersifat otentik mengenai keadaan, peristiwa, atau perbuatan hukum. Dengan dasar tersebut, mereka yang diangkat sebagai notaris harus mempunyai semangat untuk melayani masyarakat, dan atas pelayanan tersebut, masyarakat yang telah merasa dilayani oleh notaris sesuai dengan tugas jabatannya dapat memberikan honorarium kepada notaris, oleh karena itu notaris tidak berarti apa-apa jika masyarakat tidak membutuhkannya. ${ }^{5}$

\footnotetext{
4 Soerjono Soekanto \& Sri Mamudji, Penelitian Hukum Normatif, Suatu Tinjauan Singkat, Jakarta: Rajawali, 1985), 251-252

5. Habib Adjie, Sanksi Perdata..., 27.
} 
Sebagai bentuk menjalankan kekuasaan negara maka yang diterima oleh notaris dalam kedudukan sebagai jabatan (bukan profesi), karena menjalankan jabatan seperti itu, maka notaris memakai lambang negara, yaitu Burung Garuda. Dengan kedudukan seperti tersebut, maka dapat dikatakan notaris menjalankan sebagian kekuasaan negara dalam bidang hukum perdata, yaitu untuk melayani kepentingan rakyat yang memerlukan bukti atau dokumen hukum berbentuk akta otentik yang diakui oleh negara sebagai bukti yang sempurna. Sebagai pejabat umum notaris mempunyai tugas yang berat yaitu memberikan pelayanan hukum kepada masyarakat sebagai perpanjangan tangan dari Pemerintah dalam bidang hukum perdata yaitu pembuatan akta otentik guna tercapainya kepastian hukum.

Kedudukan Hukum bagi Notaris penerima protokol terhadap Notaris yang meninggal dunia, Notaris cuti maupun notaris yang purna bakti tidak membebaskan notaris dari tanggung jawabnya terhadap akta yang telah dibuatnya. Notaris penerima protokol hanya menerima dan menyimpan protokol protokol dari notaris sebelumnya. Jika terjadi permasalahan terhadap akta-akta tersebut, maka yang bertanggung jawab tetap notaris yang bersangkutan dan bukan notaris penerima protokol.

Kedudukan Hukum Notaris sebagai Pejabat Umum adalah merupakan Organ Negara yang mendapat limpahan bagian dari tugas dan kewenangan Negara yaitu berupa tugas kewajiban, wewenang dan tanggung jawab dalam rangka pemberian pelayanan kepada masyarakat umum dibidang keperdataan, khususnya dalam pembuatan dan peresmian akta.

Sebagai pejabat umum yang merupakan wakil dari pemerintah, notaris memiliki

6 Ratih Tri Jayanat, "Perlindungan Hukum Notaris Dalam Kaitannya Dengan Akta Yang Dibuatnya Manakala Ada Sengketa Di Pengadilan Negeri (Studi Kasus Putusan Pengadilan Negeri Pontianak No. kewenangan sebagaimana berdasarkan ketentuan pada Pasal 15 ayat 1 hingga ayat 3 UUJN-P. Selain memiliki kewenangan, notaris juga memiliki pembatasan kewenangan yang didasarkan pada keadaan tertentu, sehingga dalam profesi notaris dikenal adanya pemberhentian secara terhormat dari jabatannya yang sebagaimana ditegaskan dalam Pasal 8 huruf a, b, c, d dan huruf e UUJN-P. Pada Pasal 8 UUJN-P, pembatasan kewenangan notaris yang telah berakhir masa jabatannya tidak diikuti dengan adanya pembatasan tanggung jawab notaris yang telah pensiun maupun yang telah meninggal dunia. Pasal 65 UUJN-P menjelaskan bahwa Notaris, Pejabat Sementara Notaris dan Notaris Pengganti dimintai pertanggungjawaban terhadap akta yang telah dibuatnya meskipun Protokol Notaris telah dipindah tangankan kepada pihak yang ditunjuk atau diberikan hak untuk menyimpannya.

Jabatan Notaris akan terus berlangsung terus menerus meskipun seorang Notaris telah pensiun dari jabatannya sebagai Notaris, atau dengan berhentinya Notaris maka berhenti pula kedudukannya sebagai Notaris. Notaris sebagai jabatan akan tetap ada dan akta-akta yang dibuat dihadapan atau oleh Notaris yang sudah pensiun atau meninggal dunia akan tetap melekat dan diakui dan akan disimpan oleh Notaris pemegang Protokolnya. ${ }^{6}$

Terhadap protokol notaris, tanggung jawab tetap berada pada notaris pembuat akta dan bukan pada notaris penerima dan penyimpan protokol, kecuali dalam pemberian salinan akta oleh notaris penerima dan penyimpan protokol notaris terdapat perbedaan antara minuta akta dan salinan akta maka hal tersebut menjadi tanggung jawab notaris penerima dan penyimpan protokol.

72/Pdtg/Pn.Pontioanak)", Tesis, (Semarang: Program Studi Magister Kenotariatan Program Pascasarjana Universitas Diponegoro, 2010), 38 
Ketentuan yang tertuang dalam Pasal 65 UUJN-P disebutkan bahwa notaris harus bertanggung jawab terhadap setiap akta yang dibuatnya meskipun protokol notaris telah diserahkan atau dipindahkan kepada notaris lain. Ketentuan tersebut memberikan pemahaman yang multitafsir karena dalam klausa pasalnya tidak disebutkan secara tegas mengenai batas waktu seorang notaris harus mempertanggungjawabkan akta yang telah dibuatnya.

Protokol Notaris walaupun telah dipindah tangankan haruslah tetap disimpan, namun mengingat protokol notaris sebagai sebuah arsip haruslah memiliki aturan dalam pengelolaannya terutama terkait jangka waktu penyimpanan (retensi arsip). ${ }^{7}$

Pada prinsipnya, setiap kali ada Notaris yang meninggal dunia, berdasarkan Pasal 35 Undang-Undang No. 30 Tahun 2004 tentang Jabatan Notaris maka keluarganya wajib memberitahukan kepada MPD Notaris paling lambat 7 (tujuh) hari kerja. Apabila Notaris meninggal dunia pada saat menjalankan cuti, tugas jabatan Notaris dijalankan oleh Notaris Pengganti sebagai Pejabat Sementara Notaris paling lama 30 (tiga puluh) hari terhitung sejak tanggal Notaris meninggal dunia. Pejabat Sementara Notaris tersebut menyerahkan protokol Notaris dari Notaris yang meninggal dunia kepada MPD paling lama 60 (enam puluh) hari terhitung sejak tanggal Notaris meninggal dunia.

Dalam hal notaris meninggal dunia, maka protokol notaris akan diserahkan kepada notaris lain yang akan menggantikannya sebagaimana berdasarkan ketentuan pada Pasal 62 huruf a UUJN. Berdasarkan pasal ini dikatakan bahwa notaris lain yang akan menerima protokol notaris yang telah meninggal dunia adalah notaris yang ditunjuk oleh MPD. Penyerahan protokol terhadap Notaris meninggal dunia, dilakukan oleh ahli waris keluarga sedarah dalam garis lurus keturunan semenda dua Notaris dan wajib memberitahukan kepada MPD paling lama 7 (tujuh) hari kerja. Sebagaimana berdasarkan ketentuan yang tertuang pada Pasal 63 ayat (2) UUJN, Penyerahan protokol tersebut dilakukan paling lama 30 (tiga puluh) hari dengan pembuatan berita acara penyerahan protokol notaris yang ditandatangani oleh yang menyerahkan dan yang menerima protokol notaris sebagaimana berdasarkan ketentuan pada Pasal 63 ayat (1) UUJN.

Posedur Pengangkatan Pejabat Sementara Notaris dalam kasus Notaris meninggal dunia, menjadi sebuah hal yang wajib dilakukan agar tidak terjadinya kekosongan hukum dari Notaris yang meninggal dunia ke Notaris yang menerima protokol.Tugas Notaris adalah mengkonstantir hubungan hukum antara para pihak dalam bentuk tertulis dan format tertentu, sehingga merupakan suatu akta autentik. Ia adalah pembuat dokumen yang kuat dalam suatu proses hukum. ${ }^{8}$ Selain itu, tidak dialihkan sementara protokol Notaris dari Notaris meninggal dunia kepada pejabat sementara Notaris dapat menyebabkan tertundanya berbagai hal dalam pelaksanaan proses pemberian Salinan akta kepada pihak ketiga apabila minuta akta telah di tanda tangani oleh Notaris yang telah meninggal dunia tersebut. Dalam hal ini pihak ketiga tidak mendapatkan kepastian hukum akan pemberian salinan akta tersebut nantinya.

Dalam UUJN juga diatur bahwa jika Notaris meninggal dunia pada saat menjalankan cuti, tugas jabatan notaris dijalankan oleh Notaris Pengganti sebagai Pejabat Sementara Notaris paling lama 30 hari terhitung sejak tanggal Notaris meninggal dunia sebagaimana 
ketentuan Pasal 35 ayat (3) UUJN. Pejabat Sementara Notaris wajib menyerahkan Protokol Notaris dari Notaris yang meninggal dunia kepada MPD paling lama 60 hari terhitung sejak tanggal Notaris meninggal dunia sebagaimana ketentuan Pasal 35 ayat (4).

Berdasarkan Pasal 27 ayat (1) UUJN ditentukan bahwa Notaris dapat mengajukan permohonan cuti secara tertulis disertai usulan penunjukan notaris pengganti. Berdasarkan Pasal 34 ayat (1) UUJN ditentukan bahwa apabila dalam satu wilayah jabatan hanya terdapat satu notaris, Majelis Pengawas Daerah (MPD) dapat menunjuk notaris pengganti khusus yang berwenang untuk membuat akta untuk kepentingan pribadi notaris tersebut atau keluarganya. Berdasarkan Pasal 35 ayat (1) dan (2) UUJN, jika notaris meninggal dunia, suami/istri atau keluarga sedarah dalam garis lurus keturunan semenda dua wajib memberitahukan kepada MPD, dan jika notaris meninggal dunia pada saat menjalankan cuti, tugas jabatan notaris dijalankan oleh notaris pengganti sebagai pejabat sementara notaris paling lama 30 hari terhitung sejak tanggal notaris meninggal dunia. Sesuai dengan ketentuan ini, maka orang lain yang dapat mempunyai kewenangan delegasi hanyalah notaris pengganti, karena kewenangan yang diberikan kepadanya langsung dari notaris berdasarkan UUJN dan ditetapkan oleh MPD, bukan pejabat sementara notaris dan notaris pengganti khusus. Hal ini dikarenakan kewenangan yang diberikan kepadanya tidak secara langsung dari orang yang mempunyai wewenang sah atas dasar undang-undang, melainkan oleh MPD sebagaimana ditentukan dalam Pasal 34 dan Pasal 35 UUJN.

Terhadap protokol notaris, tanggung jawab tetap berada pada notaris pembuat akta dan bukan pada notaris penerima dan penyimpan protokol, kecuali dalam pemberian salinan akta oleh notaris penerima dan penyimpan protokol notaris terdapat perbedaan antara minuta akta dan salinan akta maka hal tersebut menjadi tanggung jawab notaris penerimadan penyimpan protokol.

\section{TANGGUNG JAWAB NOTARIS PENERIMA PROTOKOL NOTARIS YANG MENINGGAL DUNIA}

Tanggung jawab terbadap Diri Sendiri

Tanggung jawab terhadap diri sendiri menuntut kesadaran tiap orang untuk memenuhi kewajibannya sendiri dalam mengembangkan kepribadian sebagai manusia pribadi. Dengan demikian bisa memecahkan masalah-masalah kemanusiaan mengenai dirinya sendiri, menurut sifat dasarnya manusia adalah mahluk bermoral, tapi juga seorang pribadi. Karena merupakan seorang pribadi maka manusia mempunyai pendapat sendiri, perasaan dan angan-angan sendiri, sebagai perwujudan dari itu, manusia berbuat dan bertindak. Dalam hal ini manusia tidak luput dari kesalahan dan kekeliruan baik disengaja maupun tidak disengaja.

\section{Tanggung jawab terbadap Masyarakat}

Pada hakekatnya manusia tidak dapat hidup tanpa bantuan manusia lainnya, sesuai dengan kedudukannya sebagai mahluk sosial. Karena membutuhkan manusia lain maka ia harus berkomunikasi dengan manusia lain tersebut. Sehingga dengan demikian manusia disini merupakan anggota masyarakat yang tentunya mempunyai tanggung jawab seperti anggota masyarakat yang lain agar dapat melangsungkan hidupnya dalam masyarakat tersebut. Wajarlah apabila segala tingkah laku dan perbuatannya harus dipertanggung jawabkan kepada masyarakat.

\section{Tanggung jawab terbadap Bangsa dan Negara}

Suatu lagi kenyataan bahwa tiap manusia, tiap individu adalah warga Negara suatu Negara. Dalam berpikir, bertindak, berbuat, bertingkah laku manusia terikat oleh 
norma-norma atau ukuran-ukuran yang dibuat oleh Negara. Manusia tidak dapat berbuat semaunya sendiri. Bila perbuatan manusia itu salah, maka ia harus bertanggung jawab kepada Negara.

\section{Tanggung jawab terbadap Tuban}

Tuhan menciptakan manusia di bumi ini bukanlah tanpa tanggung jawab, melainkan mengisi kehidupannya manusia mempunyai tanggung jawab langsung tanggung jawab. Sebab dengan mengabaikan perintah-perintah Tuhan berarti mereka meninggalkan tanggung jawab yang seharusnya manusia terhadap Tuhan sebagai penciptanya, bahkan untuk memenuhi tanggung jawabnya, manusia memerlukan pengorbanan. ${ }^{9}$

\section{Tanggung jawab Moral}

Pada dasarnya moral adalah sistem nilai (sesuatu yang di junjung tinggi) yang berupa ajaran (agama) dan paham (ideologi) sebagai pedoman untuk bersikap dan bertindak baik yang di wariskan dari generasi ke generasi berikutnya. Adapun tujuan dan manfaat moral adalah mengarahkan sikap dan perilaku manusia agar menjadi baik sesuai dengan ajaran dan paham yang dianutnya dan manfaatnya adalah menjadi pedoman untuk bersikap dan bertindak atau berperilaku dalam interaksi sosial yang dinilai baik atau buruk. Tanpa memiliki moral, seseorang akan bertindak menyimpang dari norma dan nilai sosial dimana mereka hidup dan mencari penghidupan. ${ }^{10}$

\section{Tanggung jawab kepada Organisasi}

Tanggung jawab dalam perspektif moral merupakan tanggung jawab yang harus dimiliki oleh setiap Notaris. Notaris seharusnya

9 Mahisaajy, mabisaajy.blogspot.co.id/2011/03/jenisjenis-tanggung-jawab.html, diakses pada 24 Desember 2018, Pukul 16.30 WIB.

10 Prawironegoro Darsono, Filsafat Ilmu Pendidikan, (Jakarta: Nusantara Consulting, 2010), 247 melaksanakan tugas dan kewajiban sebaikbaiknya agar tujuan pembuatan akta ini tercapai dan berlaku sebagai akta yang otentik. ${ }^{11}$ Sebagai pejabat umum profesi yang menjalankan sebagian tugas kekuasaan negara dan kepercayaan masyarakat khususnya di bidang hukum privat, di samping mempunyai peranan penting dalam pembuatan akta autentik untuk kekuatan pembuktian paling sempurna, seorang notaris harus mempunyai perilaku baik yang dijamin oleh undang-undang, sedangkan undang-undang telah mengamanatkan pada perkumpulan itu untuk menetapkan dan mengatur tentang kode etik profesi notaris. Perilaku notaris berlandaskan pada kode etik profesi notaris untuk mengatur hal-hal yang harus ditaati oleh seorang notaris dalam menjalankan jabatannya dan juga di luar jabatannya.

Berkaitan dengan tanggung jawab notaris seperti yang disebutkan pada Pasal 65 UUJN menyatakan bahwa notaris bertanggung jawab atas setiap akta yang dibuatnya, meskipun protokol notaris telah diserahkan atau dipindahkan kepada pihak penyimpan protokol notaris. Ketentuan yang menunjukkan bahwa secara formil notaris bertanggung jawab atas keabsahan akta otentik yang dibuatnya dan jika ternyata terdapat cacat hukum sehingga akta tersebut kehilangan otensitasnya serta merugikan pihak yang berkepentingan maka notaris dapat dituntut untuk mengganti biaya, ganti rugi dan bunga.

Bertitik tolak dari ketentuan Pasal 65 UUJN terkait dengan pertanggung jawaban Notaris terhadap protokol-protokolnya, Notaris berkewajiban serta bertanggungjawab secara penuh terhadap seluruh protokol yang dimilikinya tersebut. Pertanggungjawabannya

11 Soegianto, "Tanggung Jawab Pendiri dan Notaris dalam Kaitannya dengan Penyetoran Modal untuk Pembuatan Akta Pendirian Perseroan", Tesis, (Semarang: Universitas Diponegoro, 2003), 51. 
tidak hanya sebatas telah usainya masa jabatannya melainkan tanggungjawabnya melekat seumur hidup Notaris.Dari segi administratif, pertanggungjawaban Notaris dalam kaitannya dengan penyimpanan dan memegang bentuk fisik setiap akta yang dibuatnya yang merupakan protokol Notaris sudah berakhir bersamaan dengan berakhirnya masa jabatan Notaris yang bersangkutan. ${ }^{12}$ Dari kedua pendapat tersebut tanggung jawab Notaris terhadap penyimpanan akta dapat berakhir namun pertanggungjawaban atas adanya sengketa atau yang kemudian timbul dari akta yang dibuatnya harus dipertanggung jawabkan seumur hidup.

Tanggung jawab notaris terjadi dalam hubungannya dalam pelaksanaan tugas dan kewajiban yang dibebankan kepada notaris berdasar wewenang yang diberikan oleh hukum. Tanggung jawab notaris timbul karena adanya kesalahan yang dilakukan notaris dalam melaksanakan tugas jabatannya, sehingga dari kesalahan tersebut timbul kerugian bagi pihak yang meminta jasa pelayanan notaris. Konsekuensi yang timbul bagi notaris sebagai pejabat umum yang diberi kewenangan dalam pembuatan akta otentik, maka ia harus bertanggungjawab dan apabila terjadi pelanggaran atau penyimpangan persyaratan pembuatan akta yang dibuatnya, maka akan membawa akibat terhadap tidak sahnya akta yang dibuat oleh notaris tersebut.

Melalui pasal ini dapat kita lihat bahwa Notaris yang akan menerima protokol Notaris yang telah meninggal dunia adalah Notaris yang ditunjuk oleh Majelis Pengawas Daerah (MPD). Penyerahan protokol tersebut dilakukan paling lama 30 (tiga puluh) hari dengan pembuatan berita acara penyerahan protokol Notaris yang ditandatangani oleh yang menyerahkan dan yang menerima protokol Notaris (Pasal 63 ayat (1) UUJN).
Dalam menjalankan jabatannya, notaris berkewajiban salah satunya adalah membuat akta dalam bentuk minuta akta dan menyimpannya sebagai bagian dari protokol notaris sebagaimana diatur dalam Pasal 16 ayat (1) huruf b Undang-undang Jabatan Notaris, dan dalam penjelasan pasal tersebut, dijelaskan bahwa kewajiban dalam menyimpan minuta akta sebagian bagian dari protokol Notaris, dimaksudkan untuk menjaga keontetikan suatu akta dengan menyimpan akta dalam bentuk aslinya, sehingga apabila ada pemalsuan atau penyalahgunaan grosse, salinan, atau kutipannya dapat segera diketahui dengan mudah dengan mencocokkannya dengan aslinya. Namun, ketentuan undang-undang Jabatan Notaris tidak menjelaskan bagaimana cara penyimpanannya.

Notaris yang meninggal dunia dan atau notaris yang diberhentikan dengan tetap, tidak perlu ada Pejabat Sementara Notaris, karena Notaris yang meninggal dunia dan diberhentikan dengan tetap tidak mempunyai kewenangan lagi artinya Jabatan Notaris yang disandangnya telah berhenti dan sudah tidak akan kembali atau diangkat lagi sebagai pejabat umum Notaris. UUJN hanya mengatur dan menjelaskan bagaimana standar dan prosedur penyimpanan minuta akta tersebut namun tidak mengatur tentang tempat penyimpanan minuta akta.

\section{KESIMPULAN}

Kedudukan Hukum bagi Notaris penerima protokol terhadap Notaris yang meninggal dunia, Notaris cuti maupun notaris yang purna bakti tidak membebaskan notaris dari tanggung jawabnya terhadap akta yang telah dibuatnya. Notaris penerima protokol hanya menerima dan menyimpan protokol protokol dari notaris sebelumnya. Jika terjadi permasalahan terhadap akta-akta tersebut,

12 Habib Adjie, Hukum Notaris Di Indonesia, (Bandung: PT. Refika Aditama, 2009), 5 
maka yang bertanggung jawab tetap notaris yang bersangkutan dan bukan notaris penerima protokol.

Notaris penerima protokol bukan pembuat akta, tanggung jawabnya hanya sebatas administratif dengan mempergunakan hak dan kewajiban ingkar dan Majelis Pengawas Notaris yang menentukan tempat penyimpanan protokol notaris yang pada saat serah terima protokol notaris telah berumur 25 tahun atau lebih hanya memiliki kewajiban untuk menjelaskan apa adanya akta yang dipegang atau disimpannya. Oleh karena itu dikenal beberapa tanggung jawab diantaranya, tanggung jawab terhadap diri sendiri, tanggung jawab terhadap masyarakat, tanggung jawab kepada bangsa / Negara, tanggung jawab terhadap Tuhan, tanggung Jawab Moral, dan tanggung jawab kepada organisasi. Uuntuk menjaga martabat lembaga notaris sebagai lembaga kepercayaan, karena karena kepercayaan masyarakat dapat turun apabila notaris tersebut melakukan pelanggaran akan bertanggung jawab secara perdata, pidana dan administrasi.

Bagi pemegang protokol notaris dapat menjalankan kewajibannya sebagaimana yang telah diatur. Dimana pemegang protokol hendaknya menjaga dan merawat minuta akta dari protokol notaris yang dipegangnya karena protokol notaris tersebut telah diamanahkan dan telah beralih tanggung jawab untuk memelihara dan menjaganya.

Semestinya ada aturan yang mengatur secara tertulis lebih lanjut mengenai pemberi protokol notaris terhadap peralihan protokol yang dibuatnya semasa bertugas kepada pemegang protokol ketika terjadi kehilangan atau pun kerusakan dikemudian hari ditangan pemegang protokol notaris. Hal ini agar memberikan perlindungan hukum bagi pemberi protokol notaris dikarenakan setelah beralih maka pemberi tidak dapat bertanggung jawab untuk kondisi apapun yang terjadi pada protokol notarisnya.

Sama halnya pemberi protokol, maka bagi penerima protokol juga hendaknya diberikan peraturan khusus dan tertulis mengenai kewajiban dan tanggung jawabnya sebagai penerima protokol. Hal ini agar penerima dapat memiliki rasa lebih bertanggung jawab lagi pada amanah yang diberikan. Sehingga ketika terjadi keadaan dimana protokol yang dipegangnya hilang atau rusak maka penerima protokol tau langkahlangkah apa yang harus dilakukan untuk menyelesaikan permasalahan. 


\section{DAFTAR KEPUSTAKAAN}

Adjie, Habib, Sanksi Perdata dan Administratif Terhadap Notaris Sebagai Pejabat Publik, Bandung: Refika Aditama, 2009. , Hukum Notaris Di Indonesia, Bandung: PT. Refika Aditama, 2009.

Darsono, Prawironegoro, Filsafat Ilmu Pendidikan, Jakarta: Nusantara Consulting, 2010.

Fajar, Mukti dan Yulianto Achmad, Dualisme Penelitian Hukum Normatif dan Empiris, Yogyakarta: Pustaka Pelajar, 2010.

Jayanat, Ratih Tri, "Perlindungan Hukum Notaris Dalam Kaitannya Dengan Akta Yang Dibuatnya Manakala Ada Sengketa Di Pengadilan Negeri (Studi Kasus Putusan Pengadilan Negeri Pontianak No. 72/Pdtg/Pn.Pontianak)", Tesis, Semarang: Program Studi Magister Kenotariatan Program Pascasarjana Universitas Diponegoro, 2010.

Kie, Tan Thong, Studi Notariat - Serba Serbi Praktek Notaris, Jakarta: Ichtiar Baru Van Hoeve, 2000. Mahisaajy, mahisaajy.blogspot.co.id/2011/03/jenis-jenis-tanggung-jawab.html, diakses pada 24 Desember 2018, Pukul 16.30 WIB.

Soegianto, "Tanggung Jawab Pendiri dan Notaris dalam Kaitannya dengan Penyetoran Modal untuk Pembuatan Akta Pendirian Perseroan", Tesis, Semarang: Universitas Diponegoro, 2003.

Soekanto, Soerjono \& Sri Mamudji, Penelitian Hukum Normatif, Suatu Tinjauan Singkat, Jakarta: Rajawali, 1985.

Waluyo, Bambang, Penelitian Hukum dalam Praktek, Jakarta: Sinar Grafika, 2002. 